\section{Stormen på København 1659 som erindringssted}

af Sebastian Olden-Jorgensen, universitetslektor, ph.d., Kobenhavns Universitets SaxoInstitut, Afdeling for Historie

Nedenstaiende artikel gengiver $i$ bearbejdet form en miniforelasning holdt den 9. februar 2011 ved presentationen of Sebastian Olden-Jorgensens bog Stormen på København 1659: Et københavnsk og nationalt erindringssted gennem 350 år, der er udgivet som bind 39 $i$ Det Kongelige Biblioteks skriftserie Danish Humanist Texts and Studies på Museum Tusculanums Forlag. V arket er en frugt af studier $i$ alle dele of Det Kongelige Biblioteks rige samlinger.

Erland Kolding Nielsen

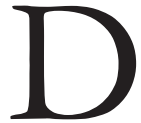
en mislykkede svenske storm på København i natten mellem den 10. og 11. februar 1659 hører til de mere dramatiske begivenheder fra Danmarkshistorien, som tidligere hvert skolebarn kendte. Selv om mindet om stormen ikke længere står så stærkt som for 100 år siden, blev 350-års-jubilæet alligevel mindet på forskellig vis i 2009. Første gang, begivenheden blev fejret som en mindedag, var i 1660, men det var først i 1661, altså for præcis 350 år siden, at "taksigelsesfesten", som dagen officielt hed, kunne fejres i hele landet. De næste godt 100 år var dagen en officiel kirkelig helligdag med obligatorisk kirkegang, klokkeringning og prædiken. Begivenheden var kort sagt blevet til et erindringssted, men hvad menes egentlig med dette ord?

\section{Hvad er et erindringssted?}

$\mathrm{I}$ begyndelsen af 1980'erne fik den franske historiker og forlagsredaktør Pierre Nora (født 1931, medlem af Academie Française 2001) en glimrende idé. Han fandt på udtrykket "lieu de mémoire", erindringssted. Han interesserede sig for den kollektive nationale erindring, og han gjorde den iagttagelse, at erindringen ikke er homogen, men koncentrerer sig, fortættes i bestemte monumenter, institutioner, personer og begivenheder. Dem kaldte han erindringssteder, og der er to ting at hæfte sig ved i den sammenhæng: Der er tale om steder både i konkret og overført betydning, og han kaldte dem ikke historiesteder, men erindringssteder. For Nora er historie og erindring komplementære og delvis modsatte begreber: Historie, det er den videnskabelige, rationelle, dokumenterbare, præcise og kritisk gennemreflekterede viden, der har universel gyldighed og kun søger sandheden. Erindring derimod er den levende, meningsfyldte, relevante, men også mangetydige og politiserede, ja subjektive viden, der altid er knyttet til konkrete erindringsfællesskaber og bruges med ganske bestemte formål. Man kunne også sige: Historie, det er fortiden i sig selv, erindring, det er fortiden for os. I erindringsstederne er det i høj grad erindringen, vi møder, men oftest - $\mathrm{i}$ hvert fald i moderne, vestlige samfund - i et stadigt med- og modspil med historien. 


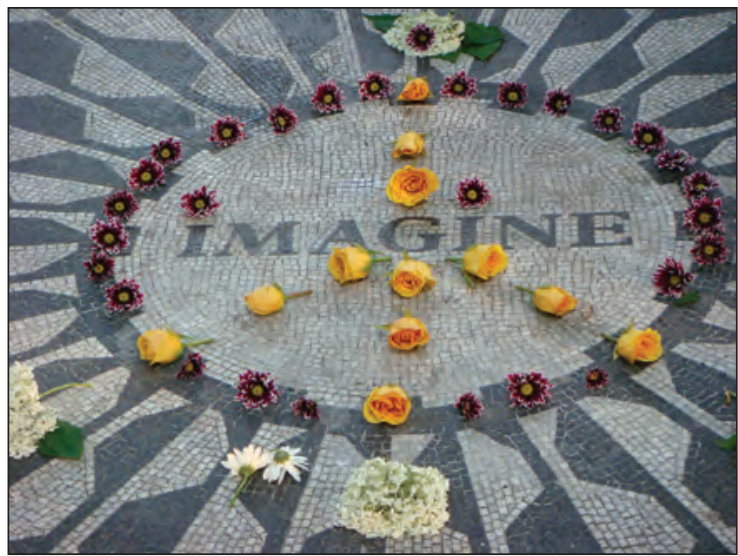

Strawberry Fields Memorial. Foto fra Wikipedia.

Frugten af Noras gode idé blev ikke kun et begreb, der siden gik ind i det almendannede franske ordforråd, men også et forskningsprojekt, der resulterede i en antologi på syv tykke bind om franske erindringssteder (Les lieux de mémoire, I-VII, Paris 1984-92, står på Læsesal Vest). Værket fik international gennemslagskraft, og det er ikke mere end et halvt år siden, at museumsinspektør Inge Adriansen kunne præsentere sin monumentale bog Erindringssteder $i$ Danmark om minde- og forsamlingssteder over hele landet. Bogen Stormen på Kobenhavn 1659 tager udgangspunkt i samme begreb, men bruger det i Noras oprindelige brede betydning og fokuserer på et enkelt erindringssted, Stormen på København 1659, der så til gengæld har en usædvanlig lang og interessant historie på hele 350 år. Men lad os først dvæle lidt ved erindringsstederne generelt.

\section{Erindringssteder af mange slags}

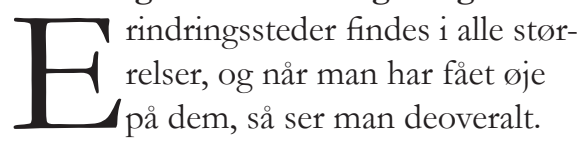

Det er jo sådan, gode begreber virker: som øjenåbnere. Det kan være konkrete steder af almen og national betydning som Dybbøl, men også begivenheder som 9. april 1940 eller befrielsen for nu at fortsætte med de nationale erindringssteder. Det kan også være institutioner som kongehuset eller personer som Christian IV eller Grundtvig eller genstande som guldhornene, og måske også håndskriftet Codex holmiensis $37 \mathrm{med}$ den ældste bevarede tekst til Jyske Lov. Og så er der alle monumenterne, fra Istedløven og den tapre landsoldat til genforeningssten overalt i landet, som Inge Adriansen har behandlet.

Selv om det er nærliggende, er der dog ingen grund til at begrænse begrebet til de nationale erindringssteder. Der findes jo også globale erindringssteder som Auschwitz og den 11. september 2001, men frem for alt findes der de mange lokale og subkulturelle erindringssteder. Et eksempel: Den 8. december 1980 blev ex-beatlen John Lennon skudt foran Dakota-bygningen i New York af den sindsforvirrede Mark David Chapman. Fem år senere åbnede 


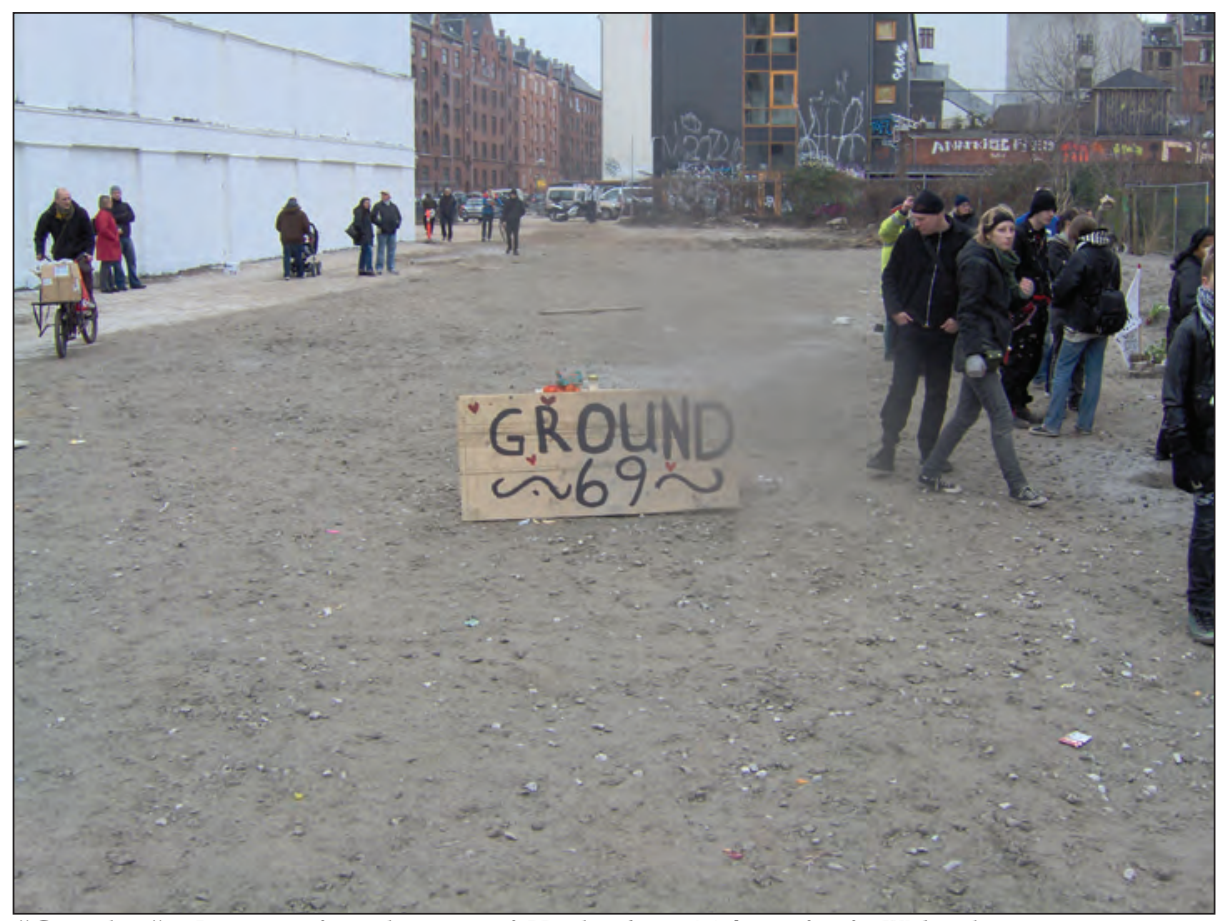

"Ground 69" - Jagtvej 69 efter nedrivningen af Ungdomshuset. Maltesen, foto fra Wikipedia.

Strawberry Fields Memorial, som er et en hektar stort område i Central Park lige neden for Dakota-bygningen. En cirkelrund kompasroseagtig mosaik danner centrum, og på den står ordet 'Imagine", der er titlen på Lennons største solohit. Dér samles folk på hans fødsels- og dødsdag under former, der minder ikke så lidt om en slags moderne, popkulturel helgenkult. Hvad er det, som her mindes? Det er ikke nemt at sige præcis, og det er også et vigtigt kendetegn ved erindringssteder, at de ikke er skarpe $i$ konturerne, men mangetydige og mildt sagt fleksible. Man går dog næppe fejl, hvis man mener, at Strawberry Fields er et erindringssted for hippiekulturen $i$ bred forstand, både æstetisk og politisk, men med tydelig overvægt af "peace, love and understanding" på bekostning af "sex, drugs and rock and roll" eller politisk radikalisme à la "The Weathermen" eller de sorte pantere.

Et lignende eksempel tættere på os selv kunne være Jagtvej 69 og nærmere betegnet rydningen af Ungdomshuset 1. marts 2007. Huset blev kort efter revet ned, og den stadig ubebyggede grund kaldes i visse kredse for "Ground 69" (i analogi med "Ground Zero" i New York). Her består det bærende erindringsfællesskab ikke som ved Strawberry Fields i New York af alverdens biologiske og kulturelle 68'ere, Beatles-fans og amerikansk østkystavantgarde, men af en mere diffus gruppe af autonome, venstrefløjsaktivister og andre, der på en eller anden 
måde, politisk eller kulturelt, føler sig knyttede til det nedrevne ungdomshus, "Ungeren" kaldet.

Hermed er mere end antydet, hvad der gør erindringssteder så relevante: De handler om identitet, værdier, følelser og politik og får deres livskraft fra de skiftende omstændigheder, de står i forbindelse med. Derfor er de også tit ensidige, foranderlige og til konstant forhandling. Et ekstremt eksempel er 11. september 2001: For nogle er det et fanatisk, terroristisk anslag mod vestlige værdier $i$ almindelighed og USA i særdeleshed, der har udløst den beklagelige, men nødvendige "war on terror". Andre tolker den som et foreløbigt højdepunkt i en uundgåelig "clash of civilizations", og atter andre ser begivenheden som den totalitære, moderne statsmagts kyniske ofring af tusindvis af menneskeliv for at retfærdiggøre yderligere overgreb på almindelige borgeres frihed. De sidstnævnte taler om "kontrolleret nedrivning” (sprængninger), mener at kende til israelsk forhåndsviden og advarsel af flere tusind jødiske ansatte $i$ bygningerne etc. - altså en konspirationsteori. Hvor de to første fortolkninger af 11. september imidlertid kan rummes inden for en dialektisk spænding mellem historie og erindring, er konspirationsteorien et eksempel på en uoverstigelig konflikt mellem historie og erindring.

Et nærliggende dansk eksempel på et omstridt erindringssted kunne være besættelsestidens samarbejdspolitik og dens ikon, statsminister Erik Scavenius: Var samarbejdspolitikken udtryk for sund fornuft, nødvendig pragmatisme eller regulær fejhed og moralsk brist?
Er Scavenius en helt, en forræder eller et offer? De forskellige svar afspejler ikke kun og måske ikke engang først og fremmest historiske vurderinger, men hænger inderligt sammen med, hvordan vi ser på os selv og vort land, på politik og moral. I parentes bemærket har også samarbejdspolitikken sin konspirationsteori, som historien må afvise. Det er myten om Rostock-mødet mellem udenrigsminister P. Munch og Heinrich Himmler den 17. marts 1940, hvor den gnidningsløse besættelse af Danmark den følgende måned angiveligt skulle være blevet aftalt.

Begrebet erindringssted er på en måde et meget pessimistisk begreb, fordi det gør opmærksom på, hvor lidt historien i Noras betydning magter over for erindringen, og fordi det noget så eftertrykkeligt belærer historikerne om, at de ikke har noget fortolkningsmonopol på fortiden. På den anden side er det også et positivt begreb, fordi det forklarer dynamikken i de stadig skiftende betydningstilskrivninger og gør opmærksom på, hvad der sker, når historien - ofte lidt hårdhændet - bruges. En sidste grund til, at erindringssted er så godt et begreb, er, at det er tværfagligt og lægger op til brede kulturhistoriske analyser som f.eks. en undersøgelse af erindringen om stormen på København 1659, sådan som den kom til udtryk i fortællinger, fejringer og genstande, $\mathrm{i}$ tekst, musik og billede.

\section{Stormen 1659}

elve den oprindelige begivenhed, den svenske storm på København natten mellem den 10. og 11. 


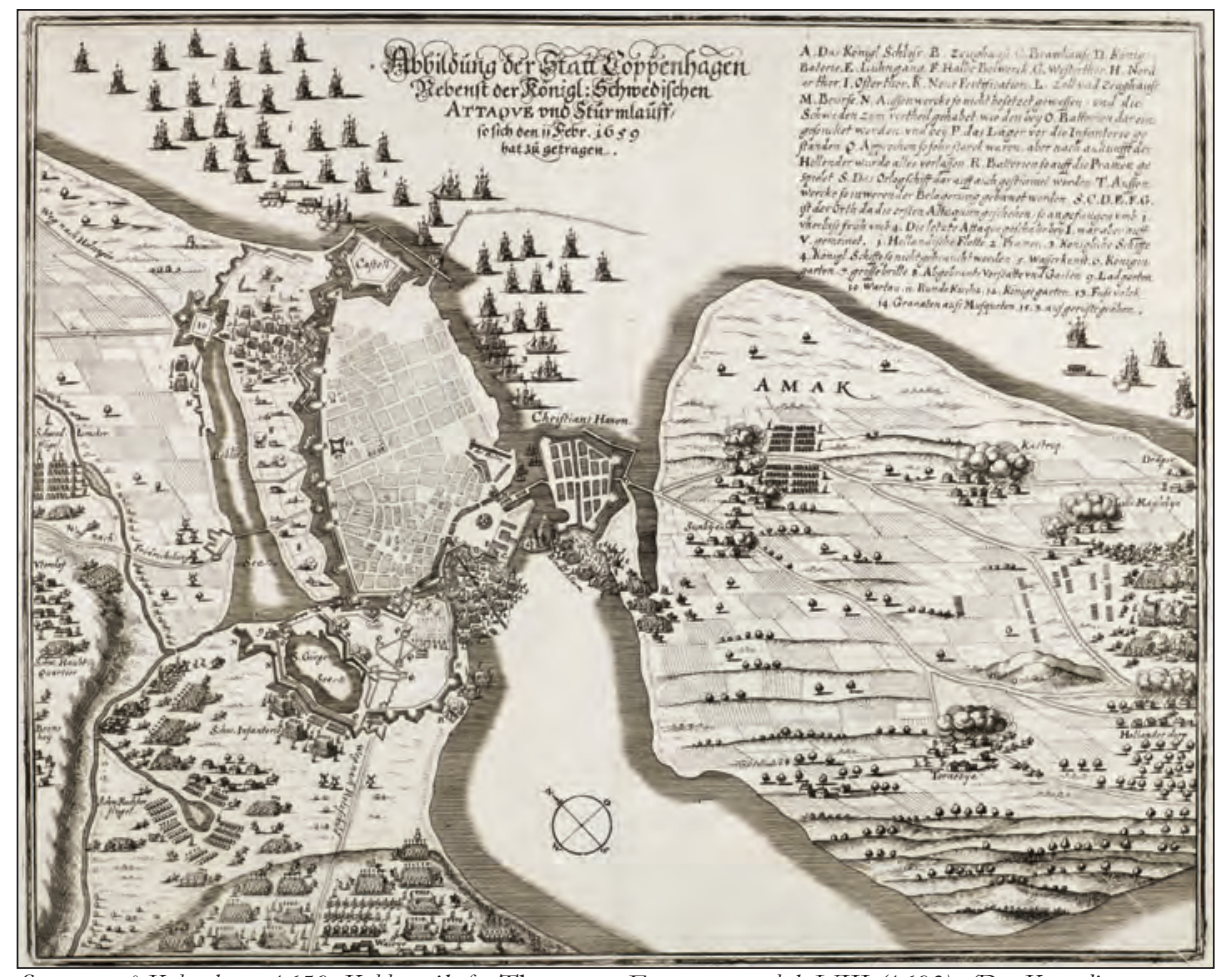

Stormen på Kobenhavn 1659. Kobberstik fra Theatrum Europæum bd. VIII (1693), (Det Kongelige Bibliotek).

februar 1659, er også i sig selv en spændende historie. Det er midt under svenskekrigene 1657-60, og svenskerne har siden august 1658 belejret København. Rent militært er der tale om dødvande, fordi en hollandsk undsætningsflåde i slutningen af oktober 1658 brød den svenske blokade fra søsiden og styrkede forsvaret. København var vel befæstet og bemandet og i øvrigt også varslet om det kommende angreb. Svenskerne havde ikke forberedt sig ved at gøre et bestemt punkt af fæstningen mørt, sådan som det ellers var almindeligt forud for et stormangreb. Stormen var militært set derfor et hovedløst foretagende, dømt til at mislykkes, og at den overhovedet blev gennemfort siger mere om den svenske konge Karl X Gustavs risikovillighed og hensynsløshed end om noget som helst andet. Og det gik, som det skulle gå. De danske tab var på højst 20 døde, heraf ingen officerer, men dog to danske adelsmænd, der tydeligvis fandt det passende at demonstrere standens eksistensberettigelse ved at udvise personligt vovemod. På svensk side ligger tabene nok i nærheden af 2000 døde, deraf 100 officerer fra generaler og nedad. Der er altså langt fra tale om nogen kritisk begivenhed, ikke nogen "Danmarks skæbnetime", hvor mandsmod, fædrelandskærlighed og kongetroskab stod sin prøve. Det var snarere en me- 


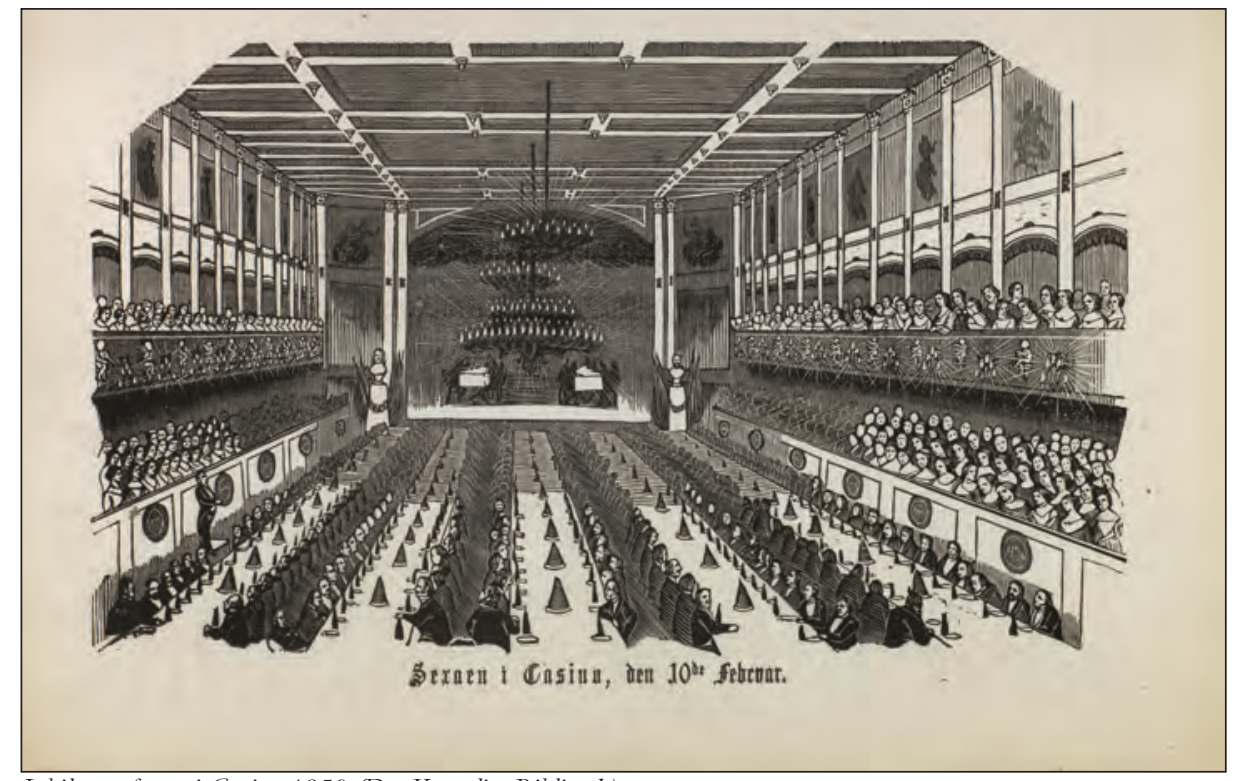

Jubilaumsfesten i Casino 1859 (Det Kongelige Bibliotek).

kanisk og stort set risikofri nedslagtning af svenske soldater, der på befaling af deres psykopatiske konge vandrede lige ind i kanonernes og musketternes dødbringende ild. Det betyder ikke, at Københavns belejring mangler mandsmod, fædrelandskærlighed og kongetroskab, men de hører til i belejringens første måneder, hvor svenskerne beskød byen med glødende kugler, og løbegravene systematisk nærmede sig Vesterport, indtil den hollandske undsætningsflåde ankom og ændrede hele situation.

\section{Stormen som officielt erindringssted}

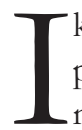

kke desto mindre var det stormen på København, som blev det nationale erindringssted. Allerede samme år blev der slået mønter, der fejrede stormen og tolkede den som Guds indgriben, og året efter blev den 11. februar gjort til en obligatorisk helligdag i hele kongeriget, der skulle markeres med gudstjeneste, prædiken og klokkeringning. Sådan fortsatte det i godt hundrede år indtil 1766, hvor festen af politiske grunde (hensynet til Sverige $i$ anledning af et ægteskab mellem en dansk prinsesse og den svenske tronarving) blev nedgraderet til næsten ingenting.

Anskuet som erindringssted må man spørge: Hvad var det, stormen på København kunne? Hvilken mening gav den? Og for hvilke grupper? Det helt korte svar lyder nogenlunde som følger: Næsten alle kunne bruge stormen til noget positivt: Kongemagten kunne mindes Frederik III's tapperhed, for han red rundt på volden hin vinternat. Desuden var det ifølge den officielle ideologi netop folkets taknemmelighed over for Frederik III's indsats under belejringen, der var årsagen til arvekongedømmets og enevældens indførelse året 
efter i oktober 1660. Københavnerne på deres side kunne bruge mindedagen for stormen eller taksigelsesfesten, som den hed, til at mindes belejringens heroiske tid, dens trængsler og de belønninger, den efterfølgende havde ført med sig $i$ form af nye og forbedrede privilegier. Der bestod et særligt bånd mellem Københavns borgere og kongemagten, og det blev skabt under belejringen og mindet ved taksigelsesfesten. Gejstligheden på sin side kunne selvsagt bruge helligdagen til at minde befolkningen om Guds godhed og det permanente behov for bod og bedring. Også adelen havde en aktie i stormen. Som nævnt satte to unge adelsmænd livet til, og både på Niels Rosenkrantz' og Niels Juels store gravmæler i henholdsvis Nikolaj Kirke og Holmens Kirke var stormen på København afbildet på relieffer. Men også blandt bønderne gav stormen på København mening. I snart sagt hver eneste landsby på Sjælland sad der efter krigen en eller flere mænd, der under belejringen havde tjent som soldater i København og oplevet stormen, og som efter krigen for sig selv og deres efterkommere var blevet fritaget for vornedskabet (en slags livegenskab). De havde personlige grunde til at mindes belejringen og stormen, og måske er det derfor, at sjællandske bønder endnu en menneskealder senere brugte stormen på København 1659 som udgangspunkt for deres egen private tidsregning.

\section{Og som borgerligt erindringssted}

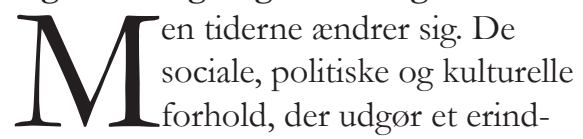

ringssteds baggrund, ændrer sig, og dermed ændrer erindringssteder også betydning eller dør. De første godt 100 år af sit liv var stormen på København et officielt erindringssted. Da det blev afskaffet som officielt erindringssted, havde det dog allerede slået solidt rod i civilsamfundet, nærmere betegnet den fremvoksende, liberale og nationalt bevidste middelstand, særlig i København. De kunne i slutningen af 1700 tallet bruge stormen på København som et eksempel på, hvordan kongen kunne stole på borgerstanden og regne med dens mod, fædrelandskærlighed og loyalitet mod kongen (i realiteten kronprins Frederik, der regerede i sin syge far Christian VII's sted). Umærkeligt var balancen dog forskudt i forhold til tidligere: Hvor det for i hvert fald officielt var Gud og kongen, der havde reddet landet og København, så var det nu borgerne, Københavns borgere, der havde reddet landet og kongen. Dem burde kongen eller rettere sagt kronprins Frederik (VI) derfor vise tillid og lytte til deres berettigede og fornuftige ønsker om økonomiske og politiske reformer.

Godt en generation senere, i 1850'erne, er billedet atter skiftet. Enevælden var faldet, og svenskerne var nu et skandinavisk broderfolk, men 250-året for stormen på København blev alligevel fejret for fuld musik over to dage i 1859. Hele det nationalliberale establishment var mobiliseret og alle guldalderens koryfæer sat i sving: H.C. Andersen, B.S. Ingemann og Christian Richardt, Orla Lehmann og Carl Ploug, Lumbye og Bournonville, de var med 


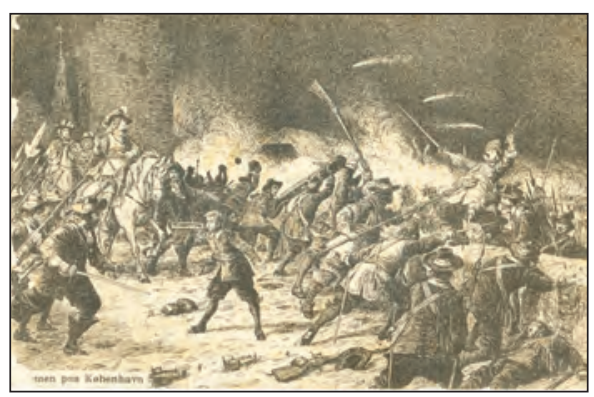

Postkort med tegning af stormen på Kobenhavn af Poul Steffensen, 1909 (Det Kongelige Bibliotek).

alle sammen, inklusive de kongelige. Blandt de sidstnævnte befandt sig også den udpegede tronfølger prins Christian (IX) af Glücksborg, som nok deltog i festivitassen med en ualmindelig dårlig smag i munden. Han var nemlig konservativ helstatsmand og vidste lige så godt som alle andre, at hele fejringen politisk set gik ud på én eneste ting, nemlig den skandinavistiske, nationalliberale Ejder-politik, som var ham så inderligt imod. Der var faktisk tale om et stykke nationalliberalt totalteater, hvor der konstant paralleliseredes mellem dengang og nu, mellem dansk heltemod og sejr i 1659 og forvisningen om, at et tilsvarende heltemod ville sikre sejren $\mathrm{i}$ den kommende konflikt med tyskerne om hele Slesvigs tilknytning til kongeriget Danmark. Man samlede mod til den kommende konflikt, og fejringen af 250-jubilæet for stormen på København er derfor en del af forhistorien til krigen 1864.

50 år senere i 1909 fejredes 300-års-jubilæet, og denne fest, der atter strakte sig over to dage, var nok den største med hensyn til volumen, for demokratiet og det moderne foreningsliv var for alvor kommet på banen.
Denne gang drejede det politisk sig om forsvarssagen, der var yderst aktuel. Få måneder før havde en forsvarskommission barslet med en betænkning, og dagen efter fejringen af stormen skulle konseilspræsident (statsminister) Niels Neergaard fremlægge lovforslag om en forsvarsordning. Hele det nationalkonservative miljø greb derfor jubilæet med begge hænder og propaganderede for et stærkt forsvar og en udbygning af Københavns befæstning. I modsætning til 1859 var samfundets eliter imidlertid uenige i spørgsmålet om forsvaret. Socialdemokraterne og de Radikale var imod, og fejringen kom langt hen ad vejen til at stå i splittelsens tegn, men blev på den anden side også markeret i snart sagt hver eneste mindre provinsby.

\section{Et dødt erindringssted}

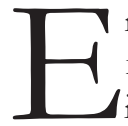
ndnu 50 år senere i 1959 havde freden sænket sig. Det var dog ikke enighed, men dødens ro, der var indtruffet. Jubilæet blev ganske vist pligtskyldigt fejret af Københavns Kommune, men under meget beskedne former uden polemik eller større bevågenhed og uden nogen form for entusiasme. Ja, tværtimod. Borgerrepræsentationens formand, socialdemokraten Sigvald Hellberg, gjorde det klart, at der egentlig ikke var noget at fejre. Han følte sig snarere fremmedgjort over for begivenheden og valgte i sin tale at dvæle ved belejringens indirekte resultat, nemlig borgerrepræsentationens forgænger, de såkaldte 32 mænd. Det er et paradoks, at netop denne ikke-fejring af stormen afsatte et officielt mindesmærke i form af mindepladen i Stormgade. 


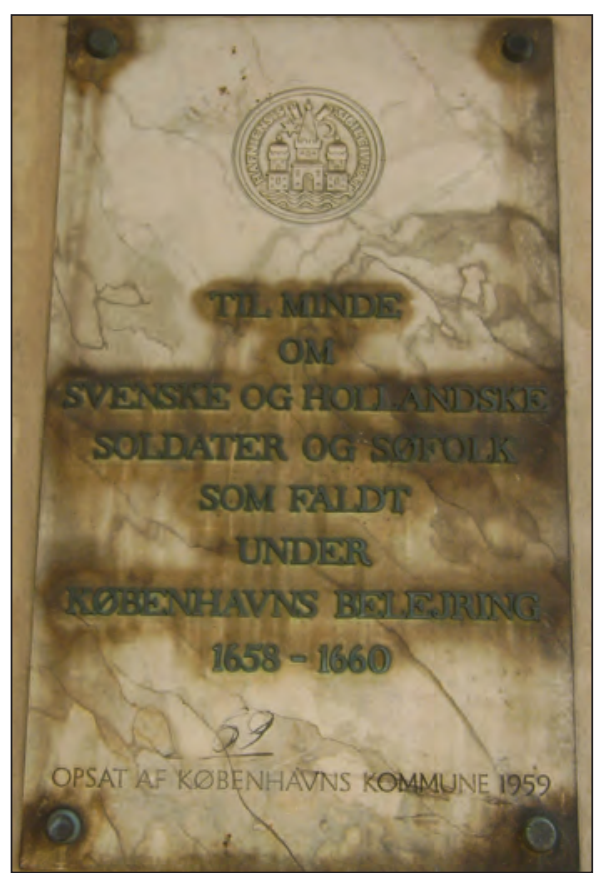

Mindepladen i Stormgade opsat 1959. Fot. Leon Jespersen.

Men denne plade er så sandelig også på det nærmeste et anti-mindesmærke. Den er nemlig ikke et minde om selve stormen endsige den danske sejr, men en mindeplade for de svenske og hollandske soldater og søfolk, der døde under belejringen. Kort sagt: Alle identitetsskabende bånd mellem selve begivenheden og det kollektiv, der opsætter mindesmærket, er borte. Der er intet budskab, ingen identitet, ingen patos, kun nøgtern og helt korrekt historisk oplysning. Historien (i Noras betydning) har sejret over erindringen.

\section{Et erindringssted kommer igen}

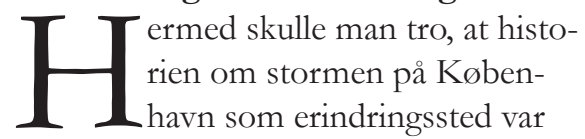

slut, men det er den ikke. Ved 350-årsjubilæet for to år siden blev stormen faktisk atter fejret med al den glød, identifikation og politisk instrumentalisering, som hører til et ægte erindringssted. Det var ikke noget stort anlagt arrangement, men det var interessant alligevel, fordi det siger meget både om vor egen tid og om et erindringssted. Der var tre grupper, der deltog i fejringen.

For det første var der en ret stor lokalhistorisk interesse. Senmoderniteten er langt fra historieløs. Måske er de gamle nationale fortællinger svækkede, og de store globale lader vente på sig, men de lokale lever i bedste velgående og udfolder stor tiltrækningskraft. De er et tidens tegn.

$$
\text { Mere overraskende er, at }
$$
stormen på København også gav genlyd i politiske miljøer både på højre- og venstrefløjen. At man i borgerlige kredse, nærmere betegnet Venstre, Konservative og de nye nationalkonservative omkring tidsskriftet Nomos, fortsat eller måske snarere atter kunne finde glæde og stolthed $i$ at mindes fortidens militære sejre er interessant, men måske ikke for alvor overraskende. Det er det derimod, at forslaget til en officiel markering af 350-årsdagen for stormen på København udgik fra Enhedslistens repræsentanter i Københavns Borgerrepræsentation. Ligesom i 1909 var Socialdemokraterne og de Radikale imod, men Venstres Kultur- og Fritidsborgmester Pia Allerslev tog Enhedslistens forslag under sine vinger, og den 11. februar 2009 blev der holdt taler for en lille skare fremmødte på Frue Plads af borgmester Allerslev, borger- 


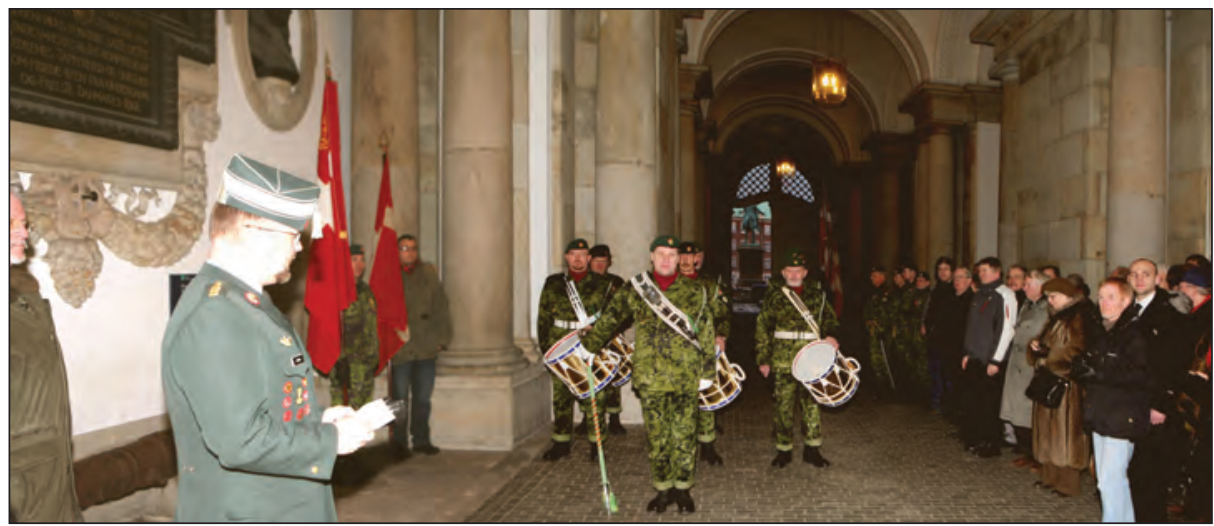

Oberst Lasse Harkjar taler ved mindehojtideligheden 2009. Fot. Peter Willems \& Tojbusmuseet.

repræsentant Allan Mylius Thomsen, den svenske ambassadør Lars Grundberg og Jesper Klein. Her blev stormen på København gjort til et eksempel på Københavns handlekraft og heltemod, men først og fremmest indskrevet i en positiv demokrati-historie, fordi belejringen som allerede tidligere nævnt førte til nye privilegier for København inklusive en forløber for Borgerrepræsentationen. Som Pia Allerslev sagde:

"Københavnerne fik natten mellem den 10.-11. februar mobiliseret moral og energi nok til at kaste svenskerne ud af byen ... vi fik etableret en institution, der gav borgerne mulighed for at blande sig i byens udvikling og $\mathrm{i}$ byens styre, og ikke længere var underlagt adelens luner og suverænitet".

Uanset hvad man måtte mene om den historiske korrekthed - forestillingen om københavnerne på volden er en myte, der blev aflivet for mindst 150 år siden, og enevælden hvilede tungt over København såvel som resten af landet de første 189 år efter stormen - så er kontrasten til 1959 slående: Identifikation, ublandet glæde og positive politiske budskaber tegner billedet.

Noget lignende, men med et helt andet budskab gjorde sig gældende lidt senere på eftermiddagen, hvor Akademisk Skyttekorps, Dansk-Skaansk Forening og Hjemmeværnet nedlagde kranse ved mindesmærket for stormen på København i Kongeporten på Christiansborg. Der er næppe mange, der kender dette mindesmærke, der i øvrigt har en meget spændende historie, men siden 1918 har Akademisk Skyttekorps nedlagt krans (fra 2010 har DanskSkaansk forening videreført traditionen). Ved kransnedlæggelsen 2009 talte Livgardens chef oberst Harkjær. Først berømmede han Frederik III's patriotisme og fastslog, at sejren skyldtes det gode samarbejde mellem de regulære styrker og de frivillige korps, dvs. borgervæbningen. Oberst Harkjær vidste med andre ord godt, at det ikke var borgere, men soldater, der stod på volden. Den traditionelle, fædrelandskærlige hyldesttale sluttede imidlertid med højst aktuelle politiske betragtninger, der tog udgangspunkt i vore dages frivillige korps, Hjemmeværnet: 
"Jeg havde ved besøg sammen med kronprinsen og forsvarsministeren i december [2008] netop mulighed for at se, hvorledes vi også i dag ser det gode samarbejde mellem de regulære hærstyrker og frivillige enheder. Kamppladsen i dag er ikke Københavns Volde, men kampen for vores frihed står i dag i Afghanistans Helmandprovins. I dag som for 350 års siden er der unge og ældre mennesker i dette land, der vil kæmpe for friheden - vores frihed. Det synes jeg vi kan være stolte over."

Sammenhængen mellem et forsvar for hovedstaden og deltagelsen i det internationale samfunds militære operationer tusindvis af kilometer væk er måske en anelse hårtrukken, men netop derfor viser citatet, hvad et ægte erindringssted formår.

\section{Slut}

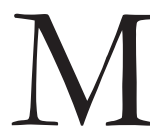

an kunne anstille mange betragtninger om det berettigede eller uberettigede i de forskellige tidsaldres og erindringsfællesskabers brug af stormen på København 1659, men det må være op til den enkelte at fælde dom. To korte konklusioner af en anden type trænger sig dog på: For det første, at begrebet erindringssted er et frugtbart analyseredskab, der giver mulighed for at anlægge interessante kulturhistoriske snit. For det andet, at når man ser på, hvordan stormen på København gennem 350 år har været tilknyttet snart sagt ethvert tænkeligt erindringsfællesskab: den samlede, tvangsindlagte befolkning, oplysningstidens opadstræbende borgerskab, hele det nationalliberale establishment, den brede nationalkonservative højrefløj og nu senest en skønsom blanding af lokalhistoriske subkulturer og småmiljøer på højre- og venstrefløjen; og når man ydermere tager $i$ betragtning, at stormen på København en overgang (1959) ligeledes på det nærmeste var død $\mathrm{i}$ den forstand, at det var de færreste, der kunne bruge den til noget positivt, men at den nu er vågnet til nyt liv; ja så er der en konklusion, der trænger sig på, og det er, at for et erindringssted er det aldrig for sent! 